\title{
Oxytocin Sustained Release Using Natural Rubber Latex Membranes
}

\author{
Natan Roberto de Barros ${ }^{1}$ - Matheus Carlos Romeiro Miranda ${ }^{1} \cdot$ Felipe Azevedo Borges $^{1}$. \\ Ricardo José de Mendonça ${ }^{2} \cdot$ Eduardo Maffud Cilli $^{1} \cdot$ Rondinelli Donizetti Herculano $^{3}$
}

Accepted: 12 March 2016/Published online: 16 March 2016

(C) Springer Science+Business Media New York 2016

\begin{abstract}
The demand for biomaterials with properties that provide sustained release of substances with pharmacological interest is constant. One candidate for applications in this area is the Natural Rubber Latex (NRL) extracted from the rubber tree Hevea brasiliensis. Recent studies indicate the NRL as a matrix for sustained release, showing promising results for biomedical applications such as: can stimulate natural angiogenesis and is capable of adhering cells on its surface, promoting the replacement and regeneration of tissue. So, the NRL is an excellent candidate to propitiate the sustained release of peptides of pharmacological interest such as oxytocin, a hormonal peptide which has the function to promote uterine muscle contractions and reduce bleeding during childbirth, and stimulate the release of breast milk. Results demonstrated that $90 \mu \mathrm{g} \mathrm{mL}^{-1}(45 \%)$ of the incorporated peptide in Natural Rubber Latex Biomedical (NRLb) functionalized membranes was released at $10 \mathrm{~h}$ in phosphate-buffered saline (PBS) solution. Swelling kinetics assay showed that the NRLb membranes are able to absorb over a period of $16 \mathrm{~h}$ up to 1.08 grams of water per grams of membrane. Scanning electron microscopy showed that the peptide was adsorbed on the surface and within NRLb membrane. Fourier transform infrared and Derivative Thermo-
\end{abstract}

Natan Roberto de Barros

natan501@ hotmail.com

1 Chemistry Institute, São Paulo State University, 55 Prof. Francisco Degni Street, 14800-060 Araraquara, SP, Brazil

2 UFTM - ICBN, 330 Manoel Mendes Square, Biochemistry Section, 38015-050 Uberaba, MG, Brazil

3 Pharmaceutical Sciences Faculty, São Paulo State University, Km01 Araraquara-Jau Road, 14801-902 Araraquara, SP, Brazil gravimetric analysis indicated that oxytocin did not interacted chemically with the membrane. Furthermore, hemolysis of erythrocytes, quantified spectrophotometrically using materials (Oxytocin, NRLb, and NRLb + Oxytocin) showed no hemolytic effects up to $100 \mu \mathrm{g} \mathrm{mL}^{-1}$ (compounds and mixtures), indicating no detectable disturbance of the red blood cell membranes. Based on these results it was possible to conclude that the NRLb has shown effectiveness as a model in the release of peptides with pharmacological interest.

Keywords Oxytocin - Natural rubber latex Peptide . Sustained release $\cdot$ Biomaterial

\section{Introduction}

The Natural Rubber Latex (NRL) is extracted from rubber tree $H$. brasiliensis, an original tree from Amazon River's watershed. After extraction, ammonium hydroxide is added to keep NRL on liquid shaped, preventing its coagulation at values close to neutral pH (Ferreira et al. 2009; Herculano et al. 2010). NRL is a mixing colloidal rubber particles stabilized by a thin layer of phospholipids and proteins (Mendonça et al. 2009). These particles are mainly composed of cis-polyisoprene, a high molecular weight polymer (D'Auzac et al. 1989); represent values between 30 and $40 \%$ of total rubber latex liquid content, and $90 \%$ of its dry weight (Hasma and Subramauian 1986).

NRL membrane has been used in biomedical applications (Mrué et al. 2004; Ferreira et al. 2009; Ereno et al. 2010; Herculano et al. 2011; Murbach et al. 2014; Borges et al. 2015), where the manufacturing method used is the Natural Rubber Latex Biomedical (NRLb), that avoids the use of chemical products as carbamates and sulfur (Pinho 
et al. 2004; Herculano et al. 2009; Romeira et al. 2012). NRLb was proposed because the NRL (previously used) shown allergic and citotoxic reactions (Allarcon et al. 2003). Alves (2003) analyzed the angiogenic stimulus from $\mathrm{NLRb}$ membranes in chicken embryo chorioallantoic membranes. The results showed that the sites where NRLb membranes was present there was a great formation stimulus of blood vessels, proving that the NRLb extracted from $H$. brasiliensis has the ability to stimulate angiogenesis. Frade et al. (2004) held a study of great social impact, where NRLb membranes were used to stimulate wound healing on pressure ulcers. The data obtained showed that the advance from necrotic to healthy wounds in 2 months. Ereno et al. (2010) used NRLb membranes in bone regeneration, where membranes were applied on bone fractures, avoiding the epithelial tissue migration and facilitating regenerative bone cells migration. These researches showed that the NRLb is effective in tissue regeneration and bone reconstitution, making this material an excellent candidate in biotechnological applications. In addition, NRLb also has been broadly used in controlled drug release systems development. Murbach et al. (2014) evaluated the NRLb use as a solid matrix in ciprofloxacin controlled release. During the experiments performed, the polymeric matrix was able to release the drug for $170 \mathrm{~h}$. In other study, Romeira et al. (2012) observed that $49.89 \%$ of Stryphnodendron $s p$. incorporated into NRLb membrane was released to $400 \mathrm{~h}$. Already Borges et al. (2014) studied the controlled release of extracts from Casearia sylvestris by NRLb membranes. It was identified the release of more than $80 \%$ of all extract incorporated into membranes. Aielo et al. (2014) showed that the release time of diclofenac in a NRLb membrane in vitro assay was increased from the typical $2-3 \mathrm{~h}$ for oral tablets to $74 \mathrm{~h}$. Pichayakorn et al. (2012) conducted a study of device based on NRLb for controlled release of nicotine. This study showed that the NRLb was able to release nicotine up to $24 \mathrm{~h}$. Guidelli et al. (2003) used the NRLb as a solid support in silver nanoparticles release. This work identified that the nanoparticles were released from the NRLb membranes up to $48 \mathrm{~h}$. Herculano et al. (2010) demonstrated the use of NRLb as a matrix for controlled release of metronidazole. In this work the amount of drug released was varied by the membranes pore modification. This pore variation was obtained by the use of low temperatures during membranes production. The author proposed the NRLb utilization as device to provide controlled and variable drug release, adjusted to the needs of the patient. So, we can conclude that the NRLb extracted can be used as solid matrix in the release of different substances, as the proposed oxytocin peptide.

Oxytocin (Fig. 1) is a hormonal peptide-produced by the hypothalamus, stored and secreted by the posterior

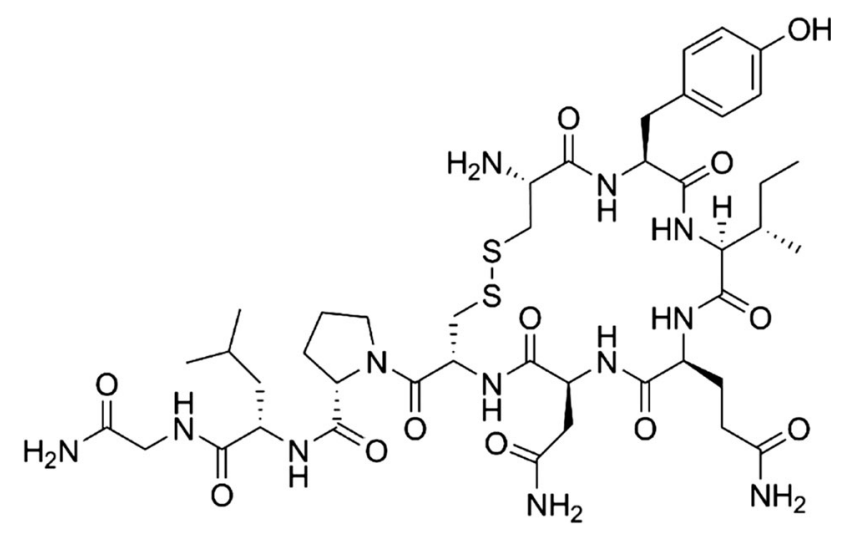

Fig. 1 Molecular structure of oxytocin

pituitary gland - which has the function to promote uterine muscle contractions and reduce bleeding during childbirth, stimulate the release of breast milk, develop attachment and empathy between people, produce part of the pleasure of orgasm, but which also produces the fear of the unknown (Lee et al. 2009). Furthermore oxytocin has solubility in water of about $12 \mathrm{mg} \mathrm{mL}^{-1}$ at $25^{\circ} \mathrm{C}$, has close to zero bioavailability, half life between 1 and $6 \mathrm{~min}$ in the bloodstream, its binding rate to proteins of the blood plasma is $30 \%$, and their disposal is bile and kidney. Recent studies indicate the role of oxytocin in various behaviors including orgasm, social recognition, anxiety, and maternal behaviors (Lee et al. 2009). For this reason it is sometimes referred to as the "bonding hormone". There is some evidence that oxytocin promotes ethnocentric behavior, incorporating trust and empathy in groups with their distrust and rejection of outsiders (De Dreu et al. 2011). Oxytocin is in the essential drugs list, a list of the most important medicines needed in a basic health system of the World Health Organization (World Health Organization 2015).

In this study, we developed a novel sustained released system containing peptides in membranes, when exposed to the skin reacts with the release of the compounds. That way, this dermal patch may be used stimulating the release of breast milk, leading thus applications of commercial and social interests, with applications not only in humans but also in animals.

\section{Methods}

The NRL used in this study was commercial high-ammonia from BDF Rubber Latex Co. Ltd. (producer and distributor of concentrated rubber latex, Guarantã, Brazil) of about $60 \%$ dry rubber content, $4-5 \%$ weight of nonrubber constituents such as protein, lipids, carbohydrates, and $35 \%$ of water. This NRL was obtained mixing two clones: 
RRIM 600 and PB 235 (Lot: 01703/13). After extraction, ammonia was used to keep the NRL liquid ( $\mathrm{pH} 10.20)$. The deproteinization of the NRL to remove allergenic proteins present in NRL was performed by centrifugation at $8000 \times g$, obtaining the Natural Rubber Latex Biomedical (NRLb) (Herculano et al. 2009; Murbach et al. 2014). The cream fraction after centrifugation was redispersed to make the desired $60 \%$ of dry rubber content latex and then washed twice by centrifugation to reduce the protein content on the solution. The NRL has $0.22 \%$ of proteins in its composition, $27 \%$ of these proteins are removed during the deproteinization process for obtaining the NRLb with $0.16 \%$ of proteins.

\section{Membranes}

NRLb membranes (Fig. 2) with oxytocin peptide were obtained from method developed by Miranda (2014). The preparation of membrane consisted of depositing $1.0 \mathrm{~mL}$ of $\mathrm{NRLb}$ and $1.0 \mathrm{~mL}$ of peptide solution in ultrapure water ( $1 \mathrm{mg} \mathrm{mL}^{-1}$ ) (equivalent to $600 \mathrm{IU}$ of biological activity) in a circular plate of diameter $22.30 \mathrm{~mm}$, and frozen using liquid nitrogen and then lyophilized for $8 \mathrm{~h}$ at $-40{ }^{\circ} \mathrm{C}$ to obtain the NRLb membranes with a thickness of $4.28 \pm 0.22 \mathrm{~mm}$. Moreover, the NRLb membranes were treated by removing loosely bound substances.

\section{Swelling Kinetics Assay}

The swelling kinetics of NRLb membranes in ultrapure water at $37{ }^{\circ} \mathrm{C}$ were measured by the gravimetric method. The sample was cut to size of $20 \times 20 \times 4 \mathrm{~mm}^{3}$ and immersed. Then, the sample was removed and the surface liquid was rapidly removed by blotting with filter paper. The swelling (Q) in the time was calculated according to Eq. (1)

$Q=\frac{W_{s}-W_{d}}{W_{d}}$

where $\mathrm{W}_{\mathrm{d}}$ is the initial weight of the sample and $\mathrm{W}_{\mathrm{s}}$ is the weight of the sample after swelling.

\section{Thermogravimetric Analysis}

The experiments were performed using thermogravimetric analyzer Netzsch STA 409. To maintain pyrolysis conditions, high purity nitrogen was used as the carrier gas. Thermogravimetric analysis were performed at $10{ }^{\circ} \mathrm{C} \mathrm{min}{ }^{-1}$ for all analysis. For experimental tests we used small pieces (about $1.50 \mathrm{~mm}$ ) of density $0.4803 \mathrm{~g} \mathrm{~cm}^{-3}$ of NRLb membranes. Weight of the NRLb samples was $0.5 \mathrm{~g}$. The samples were put in ceramic crucibles and them heated from 25 to $600{ }^{\circ} \mathrm{C}$. During the heating, the mass of the NRLb samples and furnace temperature were recorded.

\section{Fourier Transform Infrared (FTIR)}

FTIR was used to identify functional groups (amines, amides, aromatic rings, alcohol, phenols, between others), besides providing the study by possible interactions between NRLb and oxytocin. Infrared spectra of samples were studied by FTIR spectrometer in the attenuated total reflectance (ATR) method on region between 4000 and $400 \mathrm{~cm}^{-1}$, using a FTIR Spectrometer - VERTEX 70/BRUKER; source: HeNe laser; detector: DLaTGS with resolution of $4 \mathrm{~cm}^{-1}$.

\section{Scanning Electron Microscopy (SEM)}

Membrane surface and cross-section morphologies of the NRLb membranes were examined at $300 \times$ magnification using High-Resolution Scanning Electron Microscope (FEG-SEM; JEOL model 7500F) with gold as conductor material. Three aleatory areas were analyzed to perform the analysis.

\section{Release Assay}

The release assays were performed employing the venlafaxin dissolution method described by Salamon (2011) with adaptations according to USP 34 - NF 29 normative from 2011 American Pharmacopy. In glass tubes with

Fig. 2 NRLb membranes.

Notice the material is elastic,

easy manipulation and flexible

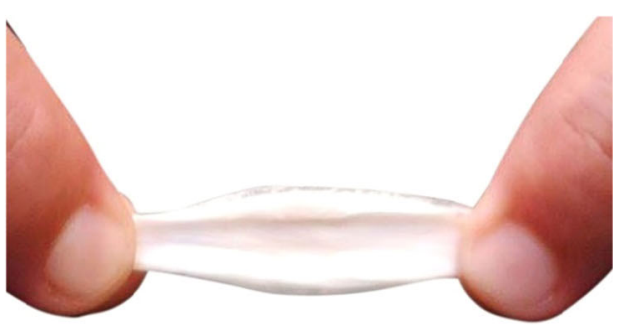


$5 \mathrm{~mL}$ phosphate buffer $\mathrm{pH}$ 7.4, NRLb membranes with oxytocin peptide were added, and maintained in constant conditions of agitation $(110 \mathrm{rpm})$ and temperature $\left(37^{\circ} \mathrm{C}\right)$.

Aliquots were analyzed in an High Performance Liquide Chromatography (HPLC) (Shimadzu model LC-10A/C47A, Japan) in analytic mode, following these chromatography conditions: Solvent A $(0.045 \%$ trifluoroacetic acid (TFA) in $\left.\mathrm{H}_{2} \mathrm{O}\right)$ and $\mathrm{B}(0.036 \%$ TFA in acetonitrile $(\mathrm{ACN}))$ in a gradient of 5-95\% (v/v) B solvent in $30 \mathrm{~min}$, at flow rate $1 \mathrm{~mL} \mathrm{~min}^{-1}$ in a C18 KROMASIL$15.0 \times 0.46 \mathrm{~cm}$ column and UV detection at $220 \mathrm{~nm}$.

\section{Hemolytic Activity}

The hemolytic activity of the oxytocin peptide, NRLb membrane, and NRLb membrane loaded with oxytocin peptide was investigated according to Onuma et al. (1999). Blood, collected from human, was centrifuged at $3000 \times g$ for $10 \mathrm{~min}$. The materials were washed four times with PBS (pH 7.4) by centrifugation at $3000 \times g$ for $5 \mathrm{~min}$ and resuspended in the same buffer. Serial dilutions of samples were used to determine the percentage of hemolysis. The final volume in each well was $200 \mu \mathrm{L}$. Then $200 \mu \mathrm{L}$ of $1 \%(\mathrm{v} / \mathrm{v})$ suspension of erythrocyte (EA) was added to each well. The wells containing complement-free buffer were used as standard with a zero degree of hemolysis (0\%); to attain $100 \%$ hemolysis, and $200 \mu \mathrm{L}$ of Triton $\mathrm{X}-1001 \%(\mathrm{v} / \mathrm{v})$ was used instead of the buffer. The plate was incubated at $37{ }^{\circ} \mathrm{C}$ for $1 \mathrm{~h}$ in Shaker Incubator (Quimis, Brazil) and then absorbance at $540 \mathrm{~nm}$ was determined in each well in an Epoch Microplate Spectrophotometer (BioTek, USA). Less than $5 \%$ hemolysis was regarded as nontoxic effect level in our experiments (Fischer et al. 2003). The percent hemolysis was calculated using the formula $100 \times\left(\mathrm{A}_{\text {sample }}-\mathrm{A}_{\text {blank }}\right) /\left(\mathrm{A}_{\text {Triton }}-\mathrm{A}_{\text {blank }}\right)$. The experiments were performed in triplicate.

\section{Results and Discussion}

\section{Swelling Assay}

The swelling kinetics of the NRLb membranes (Fig. 3) shows that the polymer matrix is able to absorb over a period of $16 \mathrm{~h}$ up to $1.08 \mathrm{~g}$ of water per grams of membrane. The low absorptive capacity of the developed matrix is due to the fact that the NRLb is a complex material, having several natural substances such as proteins and phospholipids from the rubber tree in its composition, providing a decrease in water absorption due to the presence of molecules that can cause crosslinking between polymer chains, decreasing the water entrance into the structure.

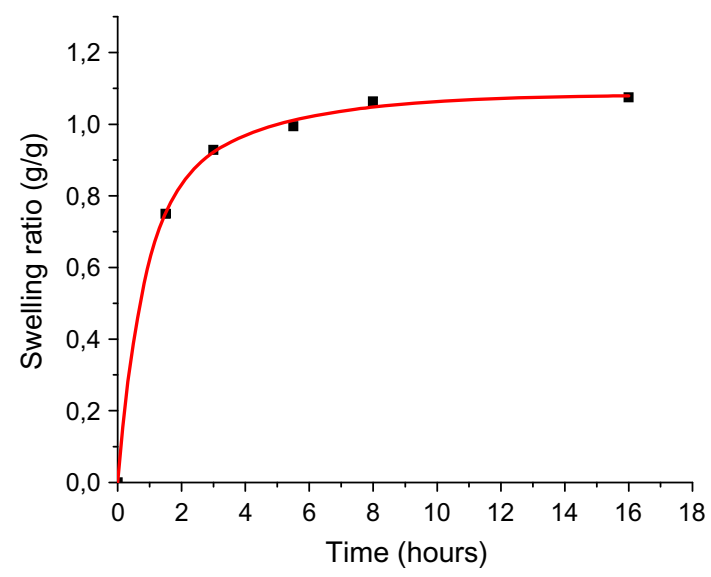

Fig. 3 The swelling kinetics of the NRLb membranes

\section{Thermogravimetric Analysis}

The derivative (DTG) thermogravimetric curves of thermal decomposition of NRLb and NRLb loaded with oxytocin pyrolysis, at heating rate $10{ }^{\circ} \mathrm{C} \mathrm{min}{ }^{-1}$ under nitrogen atmosphere, are shown in Fig. 4. As expected two regions are evident which correspond to water evaporation and active pyrolysis. The first region from 57 to $127^{\circ} \mathrm{C}$ is related to the extraction of moisture and adsorbed water in the sample. The main pyrolysis process proceeds in a range from approximately $287-472{ }^{\circ} \mathrm{C}$ for heating rate. There were no significant changes in the NRLb pyrolysis profile when oxytocin was added, indicating weak interaction between the peptide and the matrix.

\section{Fourier Transform Infrared (FTIR)}

FTIR was undertaken to evaluate the retention of peptide in the NRLb membrane. In this way, spectra of NRLb, oxytocin and NRLb loaded with oxytocin peptide were obtained to identify functional groups. Figure 5 shows

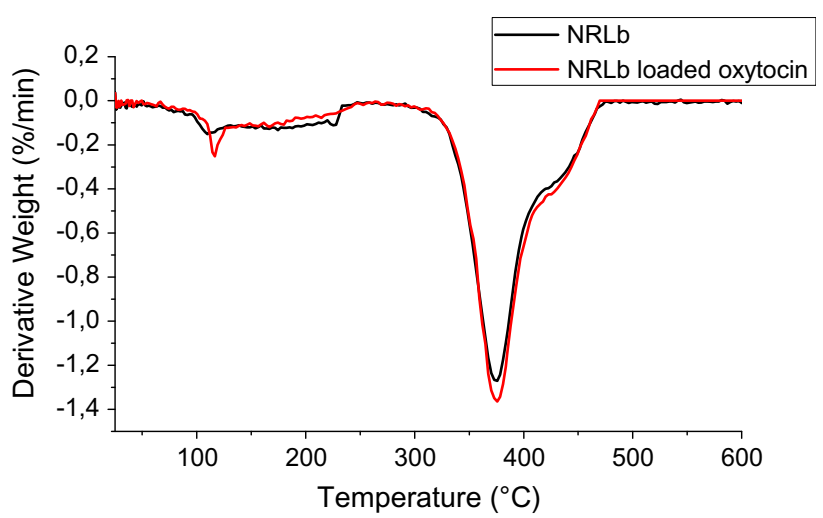

Fig. 4 Derivative thermogravimetric (DTG) curves of pure NRLb, and NRLb loaded oxytocin peptide 


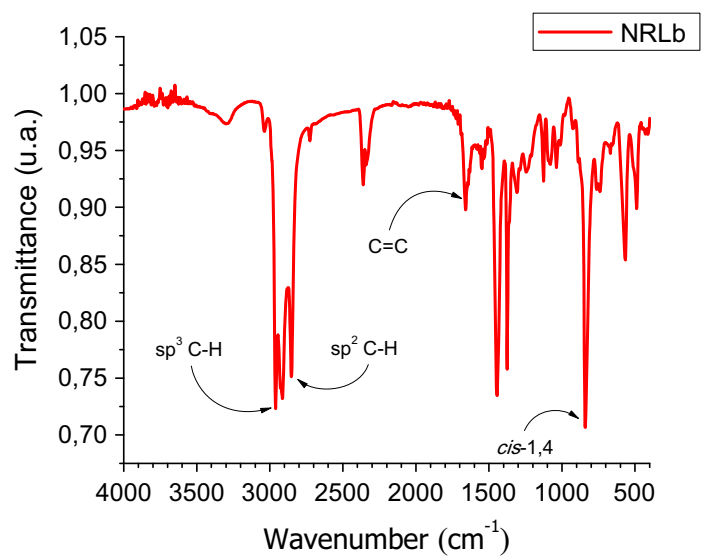

Fig. 5 FTIR-ATR spectrum from NRLb membrane

FTIR spectrum from NRLb membrane, where can identify characteristics absorption for poly(cis-1,4-isoprene): 2960 and $1375 \mathrm{~cm}^{-1} \mathrm{CH}_{3}$ strain; 2916, 2852 and $1446 \mathrm{~cm}^{-1}$ $\mathrm{CH}_{2}$ strain; $1661 \mathrm{~cm}^{-1} \mathrm{C}-\mathrm{C}$ strain and $836 \mathrm{~cm}^{-1} \mathrm{CH}$ offplan. This last absorption is the most important to identify NRL and it is character of $\mathrm{R}_{2} \mathrm{C}=\mathrm{CHR}($ cis-1,4) function in according with Murbach et al. (2014) and Borges et al. (2015).

Figure 6 shows FTIR spectrum from oxytocin peptide, where can identify absorptions $3280-3267 \mathrm{~cm}^{-1} \mathrm{NH}_{2}$ strain; $1643-1638 \mathrm{~cm}^{-1}$ amine $\mathrm{NH}$ and amides $\mathrm{C}=\mathrm{O}$ strain (when both are presents overlap occurs); $1524-1514 \mathrm{~cm}^{-1}$ aromatic $\mathrm{C}=\mathrm{C}$ strain; $1410-1403 \mathrm{~cm}^{-1}$ amines and amides C-N strain; $1260-1242 \mathrm{~cm}^{-1}$ phenol C-O and/or aromatic C-N strain (can occur overlap); $542-498 \mathrm{~cm}^{-1} \mathrm{~S}-\mathrm{S}$ strain. These FTIR correlations for oxytocin are consistent with the earlier works on characterization of protein and peptides (Barth 2007; Neda et al. 2012; Bozkurt et al. 2012).

FTIR spectra of NRLb, oxytocin (powder) and NRLb loaded with oxytocin (Fig. 7) showed that there is no covalent interaction between oxytocin and NRLb

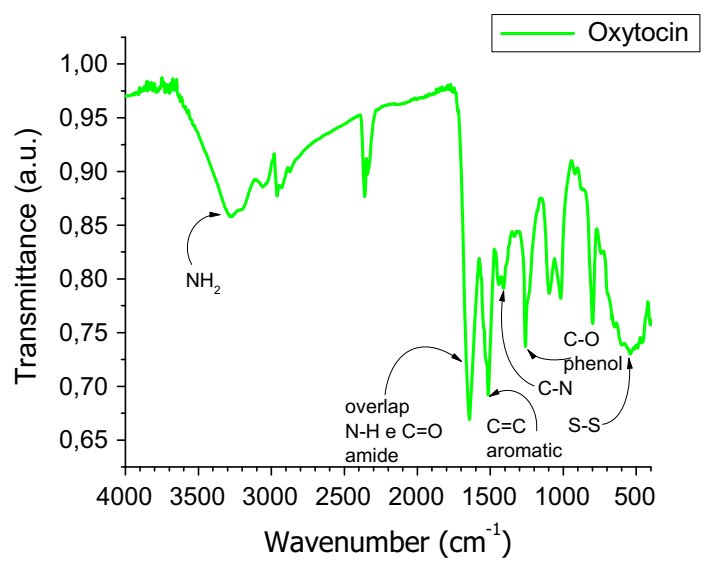

Fig. 6 FTIR-ATR spectrum from oxytocin peptide (powder)

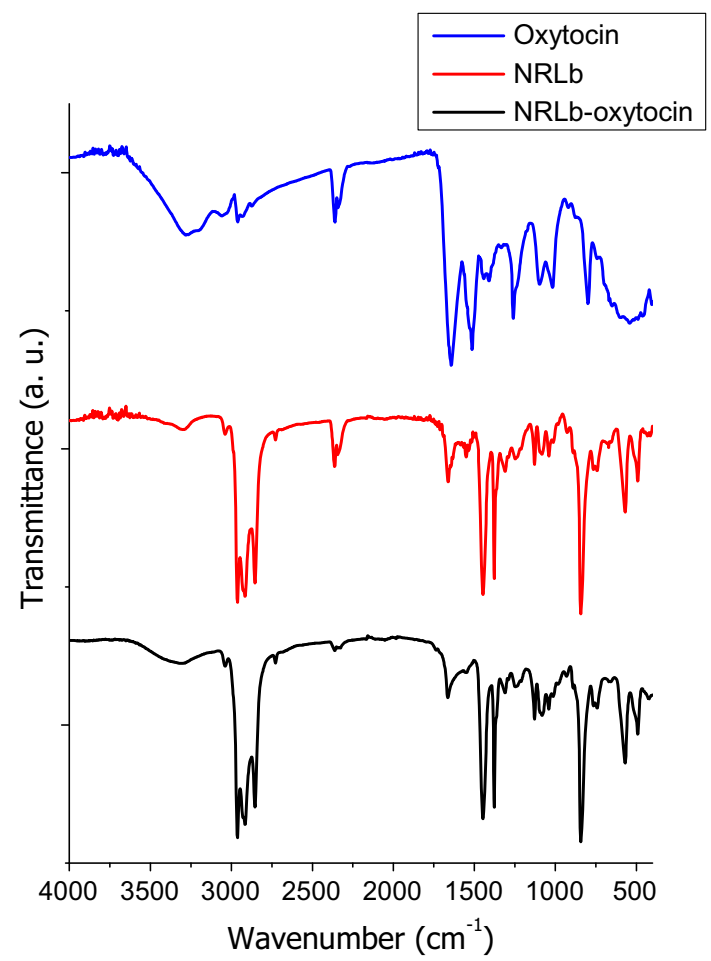

Fig. 7 Comparative FTIR-ATR spectra from NRLb, oxytocin, and NRLb membrane loaded oxytocin peptide

membrane (not show additional absorption bands). Moreover, the characteristic bands of peptide also were observed in the NRLb loaded with oxytocin. This finding indicates that NRLb membranes can retain oxytocin in its polymeric network and posteriorly release. The NRLb, an extracted natural rubber substrate from $H$. brasiliensis, presents considerable concentration of proteins in its composition (Turjanmaa et al. 1996; Blaabjerg et al. 2015; McMahan et al. 2015). By this fact, the FTIR spectra from this material exhibit characteristic absorption bands for proteins and peptides. In addition, the characteristic bands for proteins and peptides have no expressive intensity variations in the spectra obtained, also due to low peptide concentration relative into polymer matrix.

\section{Scanning Electron Microscopy}

To evaluate changes in the surface of NRLb membranes with the peptide addition, the analysis of scanning electron microscopy (SEM) was performed. The oxytocin peptide (powder), pure NRLb membrane and NRLb membrane loaded with oxytocin showed that a portion of oxytocin forms solid aggregates on the membrane surface (Fig. 8). In the Fig. $8 \mathrm{c}$ is possible to observe similar aggregates those obtained to powder peptide in the surface of membrane in according to Murbach et al. (2014) and Borges et al. (2015) that employed the NRLb membrane as solid 

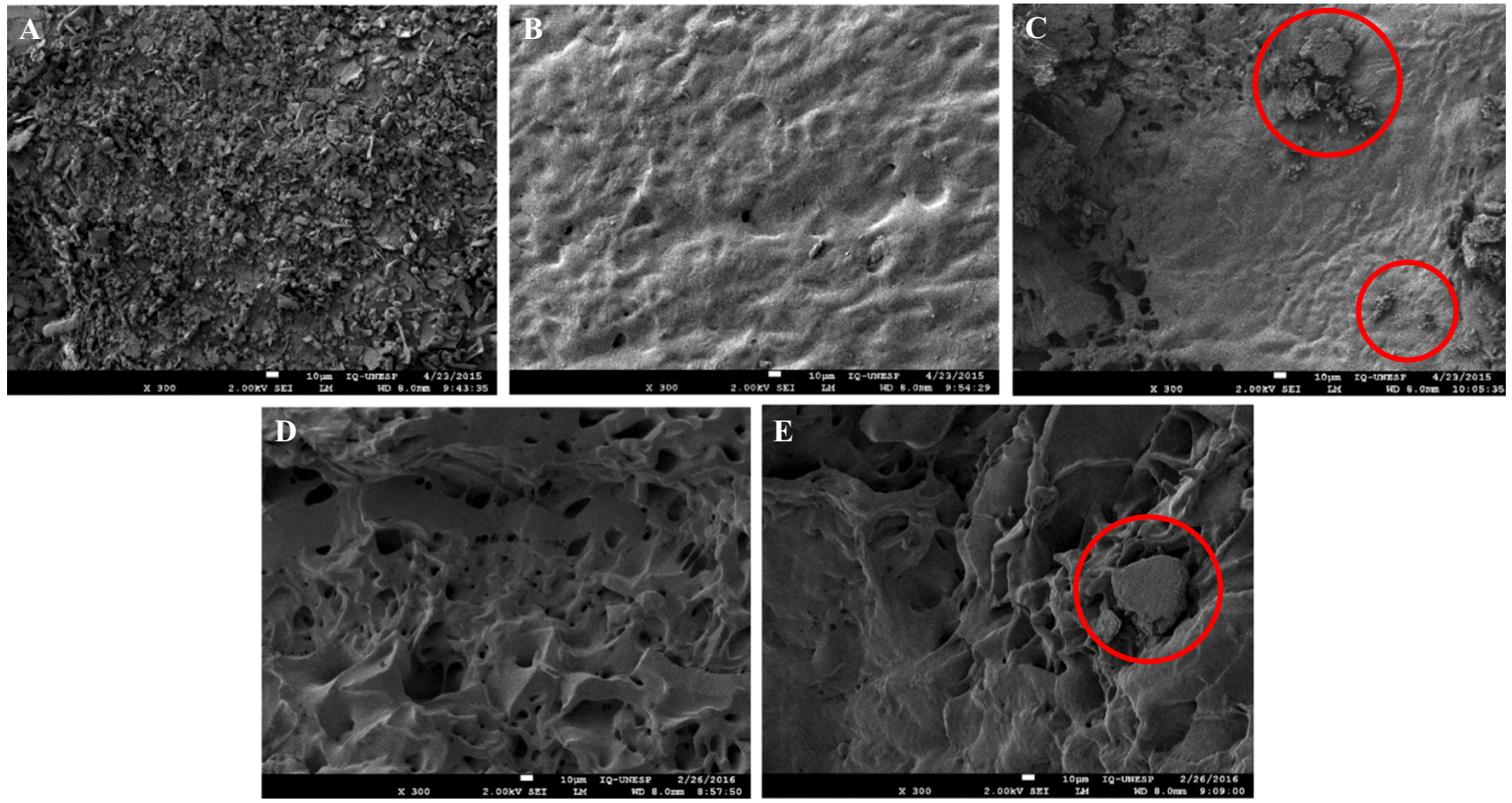

Fig. 8 Scanning Electron Microscopy of oxytocin peptide (powder-a); NRLb membrane (pure-b); NRLb membrane loaded oxytocin peptide (c); NRLb membrane (cross section-d) and NRLb membrane loaded oxytocin peptide (cross section-e)

matrix for controlled release of ciprofloxacin and Casearia sylvestris, respectively. Additionally, cross-section SEMs were performed to evaluate the porosity and the presence of peptide within the membranes. The samples were broken in liquid nitrogen in order to observe membranes crosssection. Showing the high porosity of the pure NRLb membranes when produced by the lyophilization method (Fig. 8d). On the other hand, in cross-section of NRLb membrane loaded oxytocin peptide (Fig. 8e), can be seen solid aggregates of peptide between the membrane cavities.

\section{Release Assay}

The oxytocin release evaluation by HPLC provides the chromatograms shown in Fig. 9a, where we can observe the peptide retention time of $12.3 \mathrm{~min}$ (under the conditions used). While in the Fig. $9 \mathrm{~b}$ we can see, more clearly, the change in the peptide concentration over time.

The oxytocin release kinetics revealed one bi-exponential function:

$\mathrm{y}(\mathrm{t})=\mathrm{y}_{0}+\mathrm{A}_{1} \mathrm{e}^{-\mathrm{t} / \tau 1}+\mathrm{A}_{2} \mathrm{e}^{-\mathrm{t} / \tau 2}$

where $y(t)$ is the oxytocin amount released by NRLb membrane on time function $(\mathrm{t}), \mathrm{y}_{0}$ is the initial oxytocin amount in NRLb membrane. The values for $A_{1}$ and $A_{2}$ (constants), and characteristic times $\tau_{1}$ and $\tau_{2}$ are listed in Table 1.

Oxytocin release showed two-step kinetics: (i) rapid initial release (burst release), this step is in according to the
SEM images, that shown a peptide portion on membrane surface, that is responsible for the burst release, because it dissolves faster (Huang and Brazel 2001; Thote et al. 2008); followed by (ii) slow release (stable profile) due to the oxytocin amount inside membrane.

To avoid the initial rapid release and improve the applications of NRLb membranes, the pore density can be modified on its surface with simple changes on the membrane preparation (Herculano et al. 2010). So, we can obtain different drug retention levels and hence distincts kinetics of release (slower or faster) (Romeira et al. 2012; Murbach et al. 2014).

The release profile (Fig. 10) showed that $90 \mu \mathrm{g} \mathrm{mL} \mathrm{m}^{-1}$ (45\%) of peptide incorporated by NRLb membranes was released at $10 \mathrm{~h}$ in $5 \mathrm{~mL}$ of PBS solution ( $\mathrm{pH} \mathrm{7.4).} \mathrm{The}$ drug release depends mainly on the amount of encapsulated material. Moreover, we observed that the burst release (normally short in duration) and the slower release process ("stable profile") are associated with the types of drugs incorporated the NRLb membrane. Previous studies shown that $68.40 \%$ of Bovine Serum Albumin (BSA) was released by the NRLb membranes in aqueous solution (Herculano et al. 2009), while $53.15 \%$ of the metronidazole initially incorporated in the same matrix was released (Herculano et al. 2011). Already, $59.08 \%$ of ciprofloxacin was released by NRLb membranes (Murbach et al. 2014) and the total amount of sodium and potassium diclofenac respectively released were 59.62 and $20 \%$ (Aielo et al. 2014; Barros et al. 2015). 

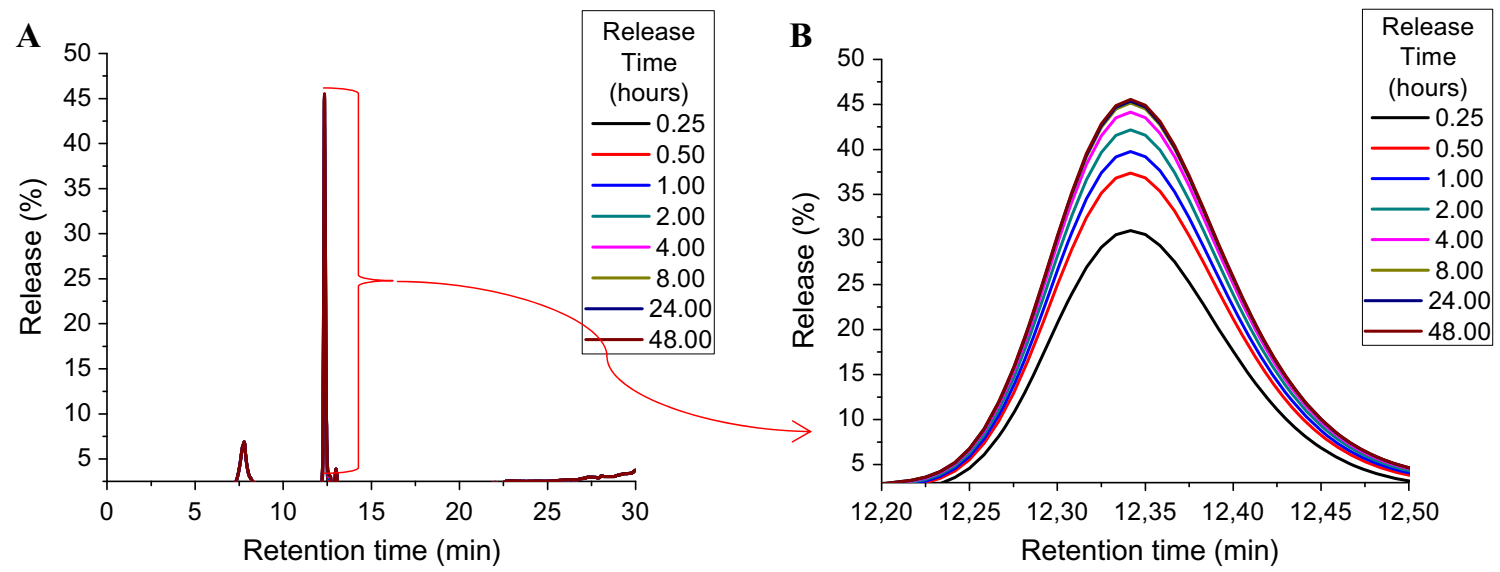

Fig. 9 Chromatograms from oxytocin release

Table 1 Values for the constants obtained from the bi-exponential function applied to the peptide release

\begin{tabular}{lcc}
\hline Equation: $\mathrm{y}=\mathrm{A}_{1} * \exp \left(-\mathrm{x} / \mathrm{t}_{1}\right)+\mathrm{A}_{2} * \exp \left(-\mathrm{x} / \mathrm{t}_{2}\right)+\mathrm{y}_{0}$ \\
\hline & \multicolumn{2}{c}{ Adj. R-Square: 0.99683} \\
\cline { 2 - 3 } & Value & Standard error \\
\hline Oxytocin & \\
$\mathrm{y}_{0}$ & 45.70599 & 0.10227 \\
$\mathrm{~A}_{1}$ & -9.69061 & 0.86218 \\
$\mathrm{t}_{1}$ & 2.0045 & 0.24087 \\
$\mathrm{~A}_{2}$ & -48.1388 & 26.49428 \\
$\mathrm{t}_{2}$ & 0.12154 & 0.03737 \\
\hline
\end{tabular}

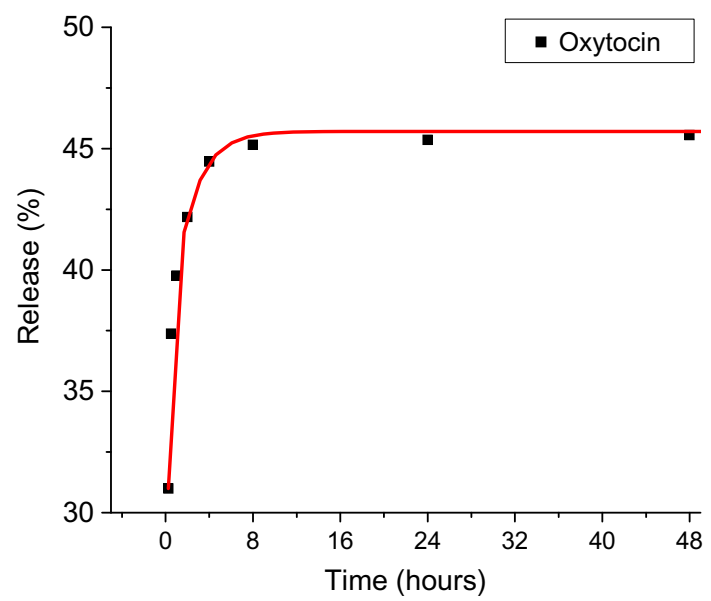

Fig. 10 Oxytocin release kinetics by NRLb membranes

Physical parameters from release depend on several mechanisms as polymeric matrix degradation, diffusion by pore density, expansion/dilatation between polymer chains, and erosion. That way, semi-empirical mathematical models were applied to evaluate which are the physic parameters involving in oxytocin release by NRLb membranes.

Table 2 shows values obtained from oxytocin kinetic release. Correlation coefficient $R^{2}$ indicates how much the mathematic model fits the profile of release presented by peptide.

The better $R^{2}$ found for oxytocin kinetic release was the Korsmeyer-Peppas mathematic model $\left(f(t)=k t^{n}\right)$, where $f(t)$ is the compound amount released from the time $t, n$ is the release exponent (this defines the release mechanism), and $k$ it is the kinetic constant (this relates structural and geometrical characteristics of the matrix). This model is applied to polymeric formulations when the release mechanism is unknown or can involve more than one mechanism (Costa 2002).

$n \leq 0.5$ indicates Fick diffusion (also known as "Higuchi equation"); $0.5 \leq n \leq 1.0$ indicates anomalous transport mechanisms; $n=1$ indicates case II transport (also known as "zero order equation", due to relaxation, swelling and polymer erosion); and $n>1$ indicates super case II transport (Steingräber et al. 2008). For oxytocin peptide, the value $n<1$ indicates that the release follows Fickian diffusion mechanism.

Table 2 Values obtained from semi-empirical mathematical models

\begin{tabular}{llll}
\hline Oxytocin & $n$ & $k\left(\mathrm{~h}^{-1}\right)$ & $R^{2}$ \\
\hline Baker-Lonsdale & & $7.25 \times 10^{-5}$ & 0 \\
Korsmeyer-Peppas & $7.07 \times 10^{-2}$ & 38.8 & 0.73 \\
Hixon-Crowell & & $2.08 \times 10^{-3}$ & 0 \\
Higuchi & & 5.36 & 0 \\
First order & $7.46 \times 10^{-3}$ & 0 \\
\hline
\end{tabular}




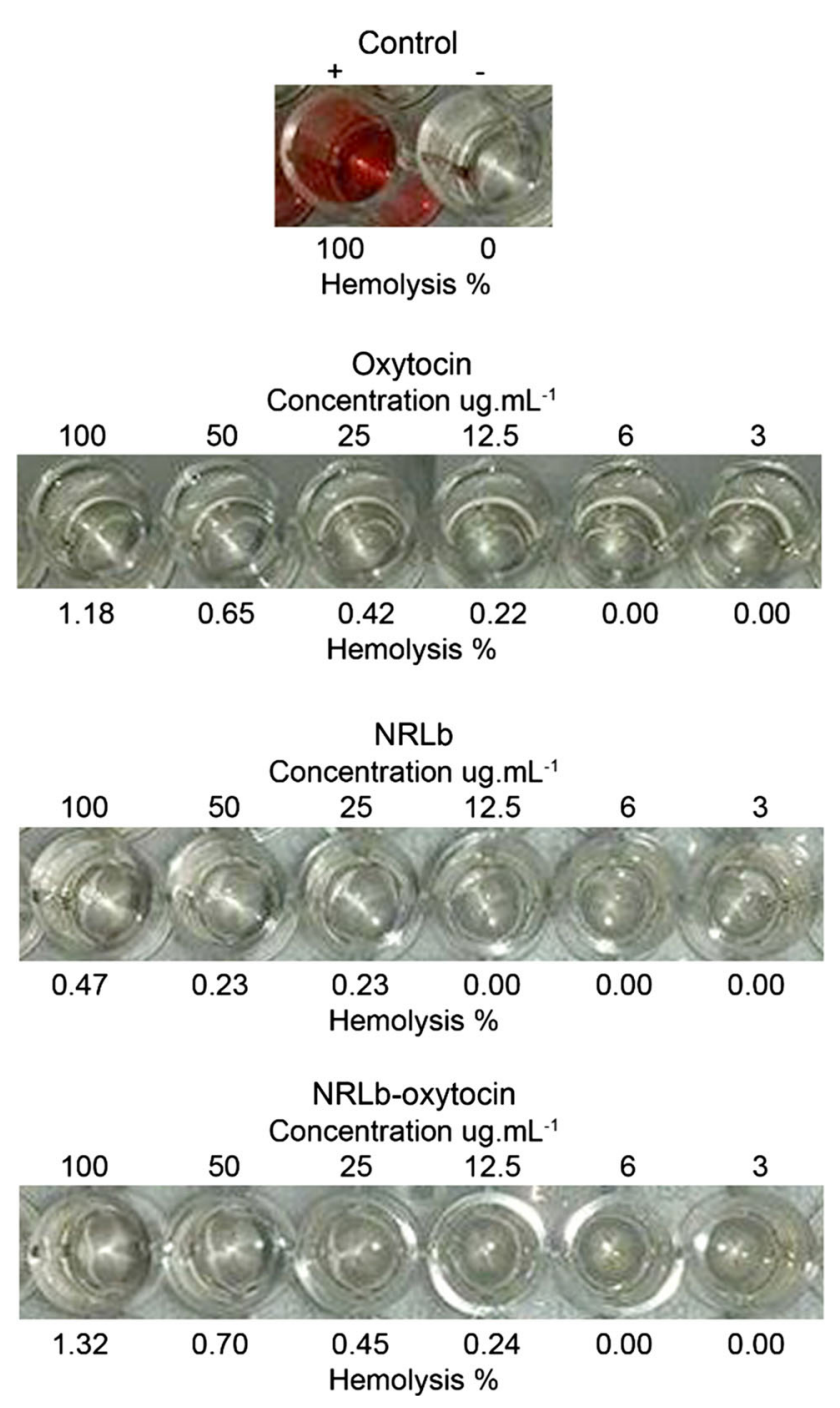

Fig. 11 Hemolysis activity as a function of materials concentrations

Table 3 Hemolytic activities of oxytocin, NRLb, and NRLb loaded with oxytocin

\begin{tabular}{llll}
\hline Concentrations $\left(\mu \mathrm{g} \mathrm{mL}^{-1}\right)$ & \multicolumn{3}{c}{$\%$ Hemolysis of human red blood cells } \\
\cline { 2 - 4 } & Oxytocin & NRLb & NRLb-oxytocin \\
\hline 3 & 0.00 & 0.00 & 0.00 \\
6 & 0.00 & 0.00 & 0.00 \\
12.5 & 0.22 & 0.00 & 0.24 \\
25 & 0.42 & 0.23 & 0.45 \\
50 & 0.65 & 0.23 & 0.70 \\
100 & 1.18 & 0.47 & 1.32 \\
\hline
\end{tabular}

Borges et al. (2014) and Murbach et al. (2014) conducted release of $C$. sylvestris extract and ciprofloxacin, respectively, employing NRLb membranes as solid matrix.
In both studies, the best mathematical model that fitted the release profile of the extract and ciprofloxacin was also the model Korsmeyer-Peppas, obtaining values $n>1$ determining release super case II transport mechanism.

\section{Hemolysis Activity}

The interactions between the oxytocin peptide, NRLb, and NRLb loaded oxytocin have also been studied by hemolysis experiments. Thereby, the hemolysis assay was performed to evaluate the cytolitic activity from the materials used. The release of hemoglobin was used to quantify the membrane-damaging properties of the materials. As 100 and $0 \%$ values we used Triton X-100 and phosphatebuffer-treated EA, respectively. EA were incubated with six different concentrations of each material in the range of 3-100 $\mu \mathrm{g} \mathrm{mL}^{-1}$ for $1 \mathrm{~h}$ (Fig. 11).

Under these conditions, oxytocin, NRLb, and NRLb loaded with oxytocin showed no hemolytic effects up to $100 \mu \mathrm{g} \mathrm{mL}^{-1}$ (Table 3) indicating no detectable disturbance of the red blood cell membranes. These results are similar to Borges et al. (2015) using coating the calcium phosphate $(\mathrm{Ca} / \mathrm{P})$ in NRLb membranes. The test was realized according to the international standard ISO 10993-4:2002, showing that the membrane NRLb-oxytocin has no cytolytic activity.

\section{Conclusion}

FTIR and thermogravimetric analysis showed that the oxytocin did not interact chemically with the NRLb membranes and that the polymeric matrix can retain the oxytocin in its polymeric network, and then release it posteriorly. NRLb membranes loaded with oxytocin peptide released at $10 \mathrm{~h}, 90 \mu \mathrm{g} \mathrm{mL}^{-1}(45 \%)$ of peptide incorporated in PBS solution. The SEM images showed that a portion of peptide remains on the membrane surface, this portion being responsible for the burst release. On the other hand, another portion of peptide remains within of polymeric matrix, being this portion reponsible for the stable profile release process. Moreover, the materials (oxytocin peptide, NRLb, and NRLb loaded with oxytocin) presented no cell damaging effects up to $100 \mu \mathrm{g} \mathrm{mL}^{-1}$, where the hemolysis level was less than $5 \%$. Based on these results it was possible to conclude that the NRLb has shown effectiveness as a model in the release of peptides with pharmacological interest.

Acknowledgments This work was supported by CAPES, CNPq and FAPESP (Processes 2014/17526-8, 2015/02343-8).

\section{Compliance with Ethical Standards}


Conflicts of Interest Author Natan Roberto de Barros declares that he has no conflict of interest. Author Matheus Carlos Romeiro Miranda declares that he has no conflict of interest. Author Felipe Azevedo Borges declares that he has no conflict of interest. Author Ricardo José de Mendonça declares that he has no conflict of interest. Author Eduardo Maffud Cilli declares that he has no conflict of interest. Author Rondinelli Donizetti Herculano declares that he has no conflict of interest.

Ethical Approval This article does not contain any studies with human participants or animals performed by any of the authors.

\section{References}

Aielo PB, Borges FA, Romeira KM, Miranda MCR, Arruda LB, Lisboa-Filho PN, Drago BC, Herculano RD (2014) Evaluation of sodium diclofenac release using natural rubber latex as carrier. Mat Res. doi:10.1590/S1516-14392014005000010

Allarcon JB, Malito M, Linde H, Brito MEM (2003) Alergia ao látex. Rev Bras Anestesiol. doi:10.1590/S0034-70942003000100012

Alves COM (2003) Teste da angiogênese estimulada por membranas de látex natural. University of São Paulo

Barros NR, Chagas PAM, Borges FA, Gemeinder JLP, Miranda MCR, Garms BC, Herculano RD (2015) Diclofenac potassium transdermal patches using natural rubber latex biomembranes as carrier. J Mater. doi:10.1155/2015/807948

Barth A (2007) Infrared spectroscopy of proteins. Biochim Biophys Acta. doi:10.1016/j.bbabio.2007.06.004

Blaabjerg MSB, Andersen KE, Bindslev-Jensen C, Mortz CG (2015) Decrease in the rate of sensitization and clinical allergy to natural rubber latex. Contact Dermat. doi:10.1111/cod.12386

Borges FA, Bolognesi LFC, Treco A, Drago BC, Arruda LB, LisboaFilho PN, Perri EG, Graeff CFO, Santos AG, Miranda MCR, Herculano RD (2014) Natural rubber latex: study of a novel carrier for Casearia sylvestris Swartz delivery. ISRN Polym Sci. doi:10.1155/2014/241297

Borges FA, Almeida-Filho E, Miranda MCR, dos Santos ML, Herculano RD, Guastaldi AC (2015) Natural rubber latex coated with calcium phosphate for biomedical application. J Biomater Sci Polym Ed. doi:10.1080/09205063.2015.1086945

Bozkurt O, Bayari SH, Severcan M, Krafft C, Popp J, Severcan F (2012) Structural alterations in rat liver proteins due to streptozotocin-induced diabetes and the recovery effect of selenium: Fourier transform infrared microspectroscopy and neural network study. J Biomed Opt. doi:10.1117/1.JBO.17.7.076023

Costa PJC (2002) Avaliação in vitro da lioequivalência de formulações farmacêuticas. Bras Cienc Farm, Rev. doi:10.1590/ S1516-93322002000200003

D'Auzac J, Jacob JL, Chrestin H (1989) Physiology of rubber tree: the composition of latex from Hevea brasiliensis as a laticiferous cytoplasm. CRC Press, Boca Raton

De Dreu CK, Greer LL, Van-Kleef GA, Shalvi S, Handgraaf MJJ (2011) Oxytocin promotes human ethnocentrism. Proc Natl Acad Sci USA. doi:10.1073/pnas.1015316108

Ereno C, Guimarães SAC, Pasetto S, Herculano RD, Silva CP, Graeff CFO, Tavano O, Baffa O, Kinoshita A (2010) Latex use as an occlusive membrane for guided bone regeneration. J Biomed Mater Res A. doi:10.1002/jbm.a.32919

Ferreira M, Mendonça RJ, Coutinho-Netto J, Mulato M (2009) Angiogenic properties of natural rubber latex biomembranes and the serum fraction of Hevea brasiliensis. Braz J Phys. doi:10. 1590/S0103-97332009000500010

Fischer D, Li Y, Ahlemeyer B, Krieglstein J, Kissel T (2003) In vitro cytotoxicity testing of polycations: influence of polymer structure on cell viability and hemolysis. Biomaterials. doi:10. 1016/S0142-9612(02)00445-3

Frade MAC, Cursi IB, Andrade FF, Coutinho-Netto J, Barbetta FM, Foss NT (2004) Management of diabetic skin wounds with a natural latex biomembrane. Med Cutan Ibero Lat Am 32(4):157-162

Guidelli EJ, Kinoshita A, Ramos AP, Baffa O (2003) Silver nanoparticles delivery based on natural rubber membranes. J Nanopart Res. doi:10.1007/s11051-013-1536-2

Hasma H, Subramauian A (1986) Composition of lipids in latex of Hevea brasiliensis clone RRIM 501. J Nat Rubb Res. 1(1):30-40

Herculano RD, Pereira CP, Ereno C, Catanzaro-Guimarães SA, Kinoshita A, Graeff CFO (2009) Natural rubber latex used as drug delivery system in guided bone regeneration (GBR). Mat Res. doi:10.1590/S1516-14392009000200023

Herculano RD, Guimarães SAC, Belmonte GC, Duarte MAH, Oliveira ONJ, Kinoshita A, Graeff CFO (2010) Metronidazole release using natural rubber latex as matrix. Mat Res. doi:10. 1590/S1516-14392010000100013

Herculano RD, de Queiroz AAA, Kinoshita A, Oliveira ON Jr, Graeff CFO, Herculano RD (2011) On the release of metronidazole from natural rubber latex membranes. Mat Sci Eng C-Biomim. doi:10.1016/j.msec.2010.09.007

Huang X, Brazel CS (2001) On the importance and mechanisms of burst release in matrix-controlled drug delivery systems. J Control Release. doi:10.1016/S0168-3659(01)00248-6

Lee H-J, Macbeth AH, Pagani JH, Young WS (2009) Oxytocin: the great facilitator of life. Prog Neurobiol. doi:10.1016/j.pneurobio. 2009.04.001

McMahan C, Kostya D, Lhamo DL, Cornish K (2015) Protein influences on guayule and Hevea natural rubber sol and gel. J Appl Polym Sci. doi:10.1002/app.42051

Mendonça RJ, Maurício VB, Teixeira LB, Lachat JJ, Coutinho-Netto J (2009) Increased vascular permeability, angiogenesis and wound healing induced by the serum of natural latex of the rubber tree Hevea brasiliensis. Phytother Res. doi:10.1002/ptr. 3043

Miranda MCR (2014) Obtenção e estudos físico-químicos de biomembranas conjugadas de látex e peptídeos bioativos. Dissertation, UNESP - Univ Estadual Paulista

Mrué F, Coutinho-Netto J, Ceneviva R, Lachat JJ, Thomazine JA, Tambelini H (2004) Evaluation of the biocompatibility of a new biomembrane. Mat Res. doi:10.1590/S1516-14392004000 200010

Murbach HD, Ogawa GJ, Borges FA, Miranda MCR, Lopes R, Barros NR, Mazalli AVG, Silvia RG, Cinman JLF, Drago BC, Herculano RD (2014) Ciprofloxacin release using natural rubber latex membranes as carrier. Int J Biomater. doi:10.1155/2014/ 157952

Neda I, Vlazan P, Pop RO, Sfarloaga P, Grozescu I, Segneanu A-E (2012) Peptide and amino acids separation and identification from natural products. InTech. doi:10.5772/51619

Onuma Y, Satake M, Ukena T, Roux J, Chanteau S, Rasolofonirina N, Ratsimaloto M, Naoki H, Yasumoto T (1999) Identification of putative palytoxin as the cause of clupeotoxism. Toxicon. doi:10. 1016/S0041-0101(98)00133-0

Pichayakorn W, Suksaeree J, Boonme P, Amnuaikit T, Taweepreda W, Ritthidej G (2012) Nicotine transdermal patches using polymeric natural rubber as the matrix controlling system: effect of polymer and plasticizer blends. J MembrSci. doi:10.1016/j. memsci.2012.04.017

Pinho ECCM, Sousa SJF, Schaud F, Lachat JJ (2004) Experimental use of latex biomembrane in conjunctival reconstruction. Arq Bras Oftalmol. doi:10.1590/S0004-27492004000100005

Romeira KM, Drago BC, Murbach HD, Aielo PB, Silva RMG, Brunello CA, Herculano RD (2012) Evaluation of 
Stryphnodendron sp. release using natural rubber latex membrane as carrier. J Appl Sci. doi:10.3923/jas.2012.693.697

Salamon BF (2011) Controle de qualidade de cápsulas de cloridrato de venlafaxina manipuladas em farmácias magistrais de Porto Alegre - RS. Dissertation. UFRGS - Univ Fed Rio Grande do Sul

Steingräber T, Schtoltz T, Rodrigues PO (2008) Avaliação da influência de adjuvantes não-poliméricos solúveis na liberação do nimodipino a partir de formulações matriciais de liberação prolongada. Rev Colomb Ciencias Quim Farm 37(2):122-132
Thote AJ, Chappell JT Jr, Kumar R, Gupta RB (2008) Reduction in the initial-burst release by surface crosslinking of PLGA microparticles containing hydrophilic or hydrophobic drugs. Drug Dev Ind Pharm. doi:10.1081/DDC-43985

Turjanmaa K, Alenius H, Makinen-Kiljunen S, Reunala T, Palosuo T (1996) Natural rubber latex allergy. Allergy. doi:10.1111/j.13989995.1996.tb04678.x

World Health Organization (2015) WHO model list of essential medicines. http://www.who.int/medicines/publications/essential medicines/en. Accessed 12 January 2015 